\title{
The Critical Role of Morale in Ukraine's Fight against the Russian Invasion
}

\author{
Jokull Johannesson \\ Institute of Strategy and Leadership, University of Agder, Kristiansand, Norway \\ Email: jokull.johannesson@uia.no
}

How to cite this paper: Johannesson, J. (2020). The Critical Role of Morale in Ukraine's Fight against the Russian Invasion. Open Journal of Social Sciences, 8, 252-260. https://doi.org/10.4236/jss.2020.86022

Received: December 17, 2019

Accepted: June 13, 2020

Published: June 16, 2020

Copyright $\odot 2020$ by author(s) and Scientific Research Publishing Inc. This work is licensed under the Creative Commons Attribution International License (CC BY 4.0).

http://creativecommons.org/licenses/by/4.0/

\begin{abstract}
The role of morale, also known as esprit de corps, in a high technology environment of the $21^{\text {st }}$ century warfare, is poorly understood. The purpose of the study is to seek evidence for the proposition that the Ukraine's population and military forces morale has neutralized the asymmetric difference in the military force of the two countries. The academic and practical implications have the potential to refocus military practice. An exploratory qualitative research method using theoretical sampling was used in this study. The study finds significant evidence for high morale as a balancing factor in the asymmetric differences of Russia and Ukraine, which explains Ukraine's success against greatly superior enemy.
\end{abstract}

\section{Keywords}

Morale, Russia, Ukraine, Donbass, War

\section{Introduction and Literature Review}

Russia has overwhelming superiority in military strength, but Ukraine has fought Russia to a standstill in the Donbass region of Ukraine. In comparison, Russian's military power dwarfs Ukraine's military forces. Still, the Russia-Ukraine war in the Donbass has been going on for many years and is locked in a stalemate where the Russian and pro-Russian forces are unable to advance against the Ukrainian military forces. Regardless of the two Minsk Peace Agreements, the war in the Ukraine Donbass is still ongoing after more than six years of conflict. Although main media coverage of the ongoing war is limited, serious fighting takes place on daily basis and this often involves heavy weapons as demonstrated by the quotes below from the situation updates given on November 26th 2019 by the Organization for Security and Co-operation in Europe (OSCE) monitors: "The security situation along the contact line in eastern 
Ukraine has seriously deteriorated with the OSCE: SMM recorded over 1000 ceasefire violations daily" (OSCE, 27/11, 2019). Even the Covid-19 pandemic did not appear to have stifled the fighting as OSCE Table of ceasefire violations as of 17 May 2020 indicates. The Table covering the ceasefire violations on the $15^{\text {th }}$ and $16^{\text {th }} 2020$ is 19 pages long (OSCE, 2020).

This article explores morale: the esprit de corps, as a plausible explanation of how Ukraine was able to fight the Russian military and pro-Russia military forces to a standstill in the Donbass region of Ukraine.

The significance of morale in military victory is recognized through history but, at present, the overwhelming focus on high technology weapon systems as source of victory on the battlefield results in a gap in the social science literature about the importance of morale in a $21^{\text {st }}$ century military conflict. Certainly, expert application of the operational art is important and so are equipment and logistical support but, the Russian military and pro-Russian forces have the advantage in these areas. So, is the morale of the Ukrainian troops the mitigating factor leveling the asymmetric differences? If so, then the implications of morale for academic research and the practical importance in $21^{\text {st }}$ century warfare merit more attention. Perhaps, General Marshall's question in Men against Fire where he explores why "a tired, cold, muddy rifleman goes forward with the bitter dryness of fear in his mouth into the mortar bursts and machine-gun fire of a determined enemy" is as a relevant question in the $21^{\text {st }}$ century as it was in WW2.

Civilians and soldiers alike can overcome incredible obstacles and challenges against overwhelming odds with little more than an inexhaustible will to win. Military history is full of examples to this point: Alexander's victory over the Persian army at Issus to Napoleon's victory in the Battle of Austerlitz; to General O'Connor army of 38,000 defeating the better equipped Italian 10th Army, numbering 160,000 men; Israel's defeat of Arab forces in the Six Day War; all are examples where an inexhaustible will to win carried the troops to victory.

Moreover, Napoleon is to have said: "In war, three-quarters depends on matters of character and morale; the balance of manpower and equipment comes only for the remaining quarter" (Napoleon I, 27 August 1808). This will to win perplexed Clausewitz who wrote: "What this inexhaustible will to win is and where it comes from is a subject of great debate with an elusive answer" (Clausewitz, 1997: p. 150; Clausewitz et al., 1984: p. 111, 127, 184).

In the same vein, Ulio (1941) considers both military morale and civilian morale as critical elements of military success as they reinforce each other. Morale is the people's commitment to a given cause of action and influences the level of hardship the soldiers and civilians alike are willing to suffer to win. However, he considers military morale different as it comes from the attitude the soldier has to the cause, his personal discipline, self-respect, pride in nation, army and group, group comradery, fundamental belief in justice and fair leadership. Additionally, Ulio (1941) considers the soldier's personal welfare and recreational opportunities critical factors contributing to morale. Perhaps, Napoleon 1st re- 
mark that "An army marches on its stomach" is as true today as it was in the 19th century.

Contemporary scholars tend to focus on the cohesion theory to explain the ability of a national military to prevail for long periods regardless of asymmetries in military strength (Castillo, 2014). Others claim that the military training and battle drills are more important than the primary group thesis proposed by Morris Janowitz and Edward Shils in 1948 (King, 2016). However, more resent study done by Pawiński and Chami (2019) proposes a new model based on The Self-Determination Theory (Ryan \& Deci, 2017) which focuses on the soldier's competence, relatedness, and autonomy. Then how do we define this elusive will to win? Anderson (2010: p. 227) defines morale as "...the secret source of an enemy's ability to sustain the activities of war" and the Royal Navy (2016) considers morale as to its manifestation: "...it [morale] manifests itself in the will to win". The fact that Ukrainian forces have valiantly fought pro-Russian and Russian forces in eastern Ukraine for more than six years indicates a will to win that is hard to ignore and contributes to the idea that at least a significant portion of the Ukrainian public has a fundamental believe in a Ukrainian identity and "self" as referred to by Feklyunia (2015). Hence, the following proposition is postulated:

Proposition 1: The Ukrainian military and population have a greater will to win than that of Russia and the Russian backed separatist forces.

There is a gap on the role of morale in the Ukraine Russia war in the literature and this article bridges this gap and seeks to explore the question of the importance of morale in the Russia-Ukraine war and suggests that morale has been the decisive factor in the defense of Ukraine. The study focuses on the Russia-Ukraine war but, the findings may be applicable to the explanation of victory in other wars where great military force asymmetry exists. The contribution of morale as a critical factor in Ukraine defense in the war with Russia has not been recognized in the literature on the war. Morale has functioned as force multiplier for Ukraine and distractor for Russia leveling the military force imbalance between the two countries.

The next section provides the results of a search for evidence for the Ukraine's military and civilian willingness to resist the Russian invasion and its implications are discussed. Then, the methods are described. Finally, a conclusion is drawn in support of the research proposition.

\section{Results}

The first part of this section provides evidence and discusses the Ukrainian military and civilian willingness to resist the Russian invasion. The second part discusses the implications for the Russian and Ukrainian governments.

Willingness to resist the Russian invasion

In March 2014, the new Ukrainian government lacked legitimacy, it was not functioning effectively, the Ukrainian military was in disarray and large portion of the Ukrainian population had a favorable perception of Russia. The EU and 
the NATO Alliance were confused and lacked a response policy. So, had Russian military forces rolled up the road from Crimea to Kiev or come down from the north, little will, or military force was there to stop them. Later, the situation was different. There was an elected functional government, the military was reorganized and reinforced. It is battle hardened and deployed for defense. The EU and the NATO Alliance have recognized the Russian threat and some policy analysis and response have been implemented such as the deployment of additional equipment to Poland. Most importantly, the Ukrainian population has suffered five years of economic hardship and the blame appears to be placed on Russia's actions.

The Ukrainian army is no pushover when it comes to the defense of the Ukrainian heartland. For more than five years, the army has been mobilizing and training men and many have gained battlefield experience in the Donbass war. In separate waves of mobilization, one hundred and ten thousand soldiers were recruited for the armed forces in 2014 and the another round of mobilization added another 50,000 men as the Verkhovna Rada (Parliament) of Ukraine approved President Poroshenko's decree "On Partial Mobilization" of January $14^{\text {th }}, 2015$. The heroic defense of the Donbass by the Ukrainian Army was a complete surprise to President Putin and the pro-Russian aggressors. Especially, when one keeps in mind the drastic defense budget cuts and asset stripping of the Ukrainian army during the Yanukovych era. The easy defeat of the Ukraine forces in the Crimea lead the Russians to think the Donbass would be another easy victory. To their surprise the Ukraine Army was boosted by volunteer brigades and public support and managed to stop the Pro-Russian attackers from advancing further into the Donbass region even with repeated heavy attacks that strong evidence suggest were supported by Russian Army units. The defense of the Donetsk airport by the Ukrainian Army's "Cyborgs" from the 3rd Special Forces Regiment (Kirovohrad), 93rd Mechanised Brigade (Dnipropetrovsk region), 79th Airmobile Brigade (Mykolaiv), 17th Tank Brigade (Kryvyi Rih) and Pravy Sector volunteer battalion shattered any dreams of quick victory by the pro-Russian forces. The Cyborgs often faced overwhelming military forces but still fought a protracted battle for nearly a year (UT, 2016).

As to the morale and determination of the Ukrainian people to resist tyranny, one can recall the determination of the unarmed people who stood on the Maidan square for weeks, in minus 20 degrees weather, while being plummeted and bludgeoned by the Berkut paramilitary police. News media reports indicate that as many as 800 thousands people attended the demonstrations on Maidan Square but, this is an estimate (Whitmore, 2013). However, I belief this estimate is only of those in the square at any one time but does not account for the droves of people coming and leaving the demonstrations via the underground stations located near the Maidan Square. In the underground stations, one could observe constant stream of people carrying Ukrainian flags coming and leaving via the subway stations escalators. A great number of people came to the Maidan Square for an hour or two then left for home. Recall, that many of the participants in the 
demonstrations were parents with children, older folks and people on a break from work, still wearing their respective uniforms as nurses, doctors, priests, enlisted men and officers etc. Historically, another indication of the Ukrainian people's morale was demonstrated when it took the Soviet Army 5 years, from 1944-59, to put down the Ukrainian Insurgent Army (UPA) in western Ukraine (Zhukov, 2007). Finally, a Gallup survey indicates $62 \%$ of Ukrainians are willing to fight for their country (Gallup, 2015). So the Russian Army will face determined defenders if it invades the Ukraine heartland. As the recent history of the fighting indicates, Ukraine has been fighting against the colossal Russian might for years and survived, which is a victory in and by itself. The morale of the Ukrainian people is reflected in President Poroshenko's (2015) statement to the media: "...But our main strength is in the fact that we are fighting for the Truth and defending our native land. Thus, our power grows multiple times."

The defense of the strategically important Mariupol is a good example of how the determination to defend a Ukrainian city works. In August 2014 Mariupol residents rallied for the City's defense and dug trenches and build fortifications (Olearchyk, 2014). While it was shortly under the control of the pro-Russian forces, Ukraine forces quickly recaptured Mariupol and have defended it against repeated attacks. The Ukrainian War Cabinet's determination to defend the city was further demonstrated in statement on 13/7 2015: "As for Mariupol, the situation is exactly opposite, relevant measures are planned to be implemented to strengthen the defense of the city as well as the planned rotation of units..." (War Cabinet, 2015) and this is exactly what needs to be communicated to the Russian government: an absolute determination to defend Ukrainian territory.

However, the picture is not all bright for the Ukraine army in terms of recruit and morale, as defections from post are common and the Ukrainian Parliament had to pass a law allowing officers to use deadly force on defectors. Nevertheless, as many as 16,000 soldiers are absent without leave and one half of draftees for the $6^{\text {th }}$ army mobilization campaign may have dodged (Novorossia, 2015). The Russian Army has problems in this area too. Soldiers lack the motivation to fight in Ukraine and some have quit the Russian Army because of the pressure to volunteer for contract soldiering in Ukraine (Tsvetkova, 2015).

Implications

The implications for Russia are the need to avoid full scale military assault on Ukraine because the opportunity for an easy victory is lost and the civil and military morale is high as demonstrated by six years of effort has resulted in a stalemate. Perhaps, moving forward, one option for Russia is to continue its hybrid warfare with the objective to slowly drain Ukraine of resources and the will to fight resulting in the collapse of the pro-western governments. Another option for Russia is to take a page out of PLA's notebook on the Sino-Vietnamese War in 1979 and declare a victory and go home. This option takes the pressure of Russia, is likely to result in the lifting of the sanctions imposed and the pro-western Ukraine governments may ultimately collapse on their own. Finally, Russia's alternative is to utilize hybrid tactics such as: economic-, diplomatic-, 
information- and cyber warfare and proxy pro-Russian military forces and that is seemingly what Russia has been doing. Berzins (2014) suggest that Russia has chosen these hybrid tactics but, it is not commonly understood that Russia uses these hybrid tactics because of a lack of conventional military resources and because of the high morale displayed by people and military of Ukraine.

The implications for Ukraine are many. Ukrainian leaders need to make it crystal clear to the leaders in Moscow that Ukraine will use all available means to defend Ukraine sovereignty: including weapons of mass destruction and measure need to be taken to develop them, that Ukraine will be defended in depth, cities will be fortified like Mariupol, scorched earth orders will be issued for threatened territories and, that Ukraine will retaliate with attacks on targets in Russia. Moreover, the Ukraine government must defend against the information, economic, and diplomatic warfare tactics Russia uses. The Russian information warfare tactics needs to be explained to the Ukrainian public and measures need to be taken to combat it by electronic means and restriction on pro-Russian propaganda. However, economic reforms are a key to the continued public support for the defense of Ukraine from pro-Russian forces. People must have necessities and a hope of future economic prosperity. The full and rapid implementation of the Coalition Agreement by the Program of the Cabinet of Ministers and Strategy 2020 and the IMF-Ukraine Memorandum of Economic and Financial Policies are critical for the economic progress the public want and provide a basis for increased foreign investment leading to economic prosperity.

The implications for the research are more focus needs to be given to the significance of morale in modern warfare as this may be the plausible explanation for victory in other asymmetric wars in the $21^{\text {st }}$ century such as the wars in Afghanistan, Iraq and Yemen.

The implications for political- and military practice is to focus on keeping the population and military morale at a high level both in their own countries and those of their allies.

The implications for major military powers are to emphasize operations that attack the enemy's fundamental will to fight and most likely by soft power techniques and propaganda.

\section{Methodology}

This explorative study uses grounded research methodology to solve the immediate problem of understanding the role of morale in international conflict in the 21 st century. Researchers consider exploratory research methodology appropriate when generation of new explanations for a phenomenon is needed and the problem does not easily lend itself to hypothesis testing with quantitative methods (Glaser \& Strauss, 1967: p. 28; Roberts \& Dunworth, 2012; Wright \& Schartner, 2013).

Theoretical sampling was used to collect data for evidence leading to the development of the article (Ghauri \& Gronhaug, 2005: p. 149; Strauss, 1987: p. 16). 
The role of morale was used to guide the collection of secondary information. Comparison of different data sources was used for reliability as endorsed by researchers (Yin, 2013; Ferrier, 2001; Levy, 2008; Ghauri \& Gronhaug, 2005: p. 196).

Literature review, open source articles, government reports, news reports and websites were used as sources of evidence for this article. Additional insight was developed by observation during frequent visits to Ukraine and discussions with eyewitnesses which also provided cross referencing of the secondary evidence as done by Mintzberg (1979). The author participated in security conferences, had discussions with academics in the security- and international relations fields and had informal discussion with serving and retired offices in the Armed Forces of Ukraine. Some researchers have recognized the advantage of such close connection with research subject as it enhances access and observation (Glaser \& Strauss, 1967: p. 156; McFarland \& Stansell, 1993). The exploratory qualitative case study methodology is widely accepted in the international relations and political science literature and most of the recent studies on the Ukraine-Russia conflict are indeed qualitative in nature as the phenomena do not lend itself readily to statistical or other Neo-Newtonian analysis.

Suggestions for further studies include the research into the role of morale in the wars in Afghanistan and Yemen where useful lesson may be learned of how appealingly vastly inferior forces, at the least in technological and logistical terms, have gained ground against well equipped and supplied armed forces.

\section{Conclusion}

The high morale of the Ukrainian military and civilian population has multiplied the Ukrainian army's defense power in the war with Russia. In comparison, the low morale of the Russian supported forces and military has neutralized Russia's overwhelming military superiority over Ukraine making it unlikely that Russia has the military forces to invade Ukraine without seriously endangering the defense of Russian border areas. If Russia does take the risk of a full-scale military attack on Ukraine, then Russia that does not have the morale will be necessary to hold and control Ukraine. Therefore, a full-scale Russian invasion of Ukraine is not going to occur, and Russia must resort to alternative strategy and tactics to gain influence in Ukraine.

The challenge for the Ukraine's government is to maintain the support of the general population for the war and keep up the morale of the fighting forces and their commanders. Furthermore, the Ukraine's government needs to increase the international pressure on Russia by lobbying the European Union and the United States for support and the maintenance of the sanctions imposed on Russia.

\section{Conflicts of Interest}

The author declares no conflict of interest. 


\section{References}

Anderson, B. (2010). Morale and the Affective Geographies of the "War on Terror". Cultural Geographies, 17, 219-236. https://doi.org/10.1177/1474474010363849

Berzins, J. (2014). Russia's New Generation Warfare in Ukraine: Implications for Latvian Defense Policy. Policy Paper, 2, 2002-2014.

Castillo, J. J. (2014). Endurance and War: The National Sources of Military Cohesion. Palo Alto, CA: Stanford University Press. https://doi.org/10.11126/stanford/9780804789103.001.0001

Clausewitz, C. V. (1997). War, Politics, and Power: Selections from on War, and I Believe and Profess. Washington DC: Regnery Publishing.

Clausewitz, C. V., Howard, M., \& Paret, P. (1984). On War. Princeton, NJ: Princeton University Press.

Feklyunia, V. (2015). Soft Power and Identity: Russia, Ukraine and the "Russian World(s)". European Journal of International Relations, 22, 773-796. https://doi.org/10.1177/1354066115601200

Ferrier, W. J. (2001). Navigating the Competitive Landscape: The Drivers and Consequences of Competitive Aggressiveness. Academy of Management Journal, 44, 858-877. https://doi.org/10.2307/3069419

Gallup (2015). WIN/Gallup International's Global Survey Shows Three in Five Willing to Fight for Their Country.

http://gallup.com.pk/wp-content/uploads/2015/12/1803151.pdf

Ghauri, P. N., \& Grønhaug, K. (2005). Research Methods in Business Studies: A Practical Guide. London: Pearson Education.

Glaser, B. G., \& Strauss, A. L. (1967). The Discovery of Grounded Theory: Strategies for Qualitative Research. New Brunswick, NJ and London: Aladine Transaction Publishers.

King, A. (2016). On Combat Effectiveness in the Infantry Platoon: Beyond the Primary Group Thesis. Security Studies, 25, 699-728. https://doi.org/10.1080/09636412.2016.1220205

Levy, J. S. (2008). Case Studies: Types, Designs, and Logics of Inference. Conflict Management and Peace Science, 25, 1-18. https://doi.org/10.1080/07388940701860318

McFarland, K. P., \& Stansell, J. C. (1993). Historical Perspectives. In L. Patterson, C. M. Santa, K. G. Short, \& K. Smith (Eds.), Teachers Are Researchers: Reflection and Action (pp. 12-18). Newark, DE: International Reading Association. https://doi.org/10.1557/S0883769400038999

Mintzberg, H. (1979). An Emerging Strategy of “Direct” Research. Administrative Science Quarterly, 24, 582-589. https://doi.org/10.2307/2392364

Napoleon, I. (1808). Dictionary of Quotations (p. 480). Glasgow: HarperCollins Publishers.

Novorossia (2015). 16,000 Ukrainian Troops Defected Donbass with Weapons, Prosecutor Says Novorossia, October 5, 2015. https://tass.com/world/826234

Olearchyk, R. (2014). Mariupol Digs in and Waits for Russians. Financial Times: Europe. https://www.ft.com/content/cf563ec8-2f9a-11e4-83e4-00144feabdc0

OSCE (2020). Table of Ceasefire Violations as of 17 May 2020. https://www.osce.org/files/5/a/table_ceasefire--2020-05-17.pdf?download=true

OSCE (2019). Status Report. OSCE Special Monitoring Mission to Ukraine (SMM). https://www.osce.org/special-monitoring-mission-to-ukraine/440279?download=true 
Pawiński, M., \& Chami, G. (2019). Why They Fight? Reconsidering the Role of Motivation in Combat Environments. Defense Studies, 19, 297-317. https://doi.org/10.1080/14702436.2019.1632198

Poroshenko, P. (2015). http://www.president.gov.ua/en/news/prezident-oglyanuv-vistavku-vijskovoyi-tehnikido-dnya-zahis-36147

Roberts, P., \& Dunworth, K. (2012). Staff and Student Perceptions of Support Services for International Students in Higher Education: A Case Study. Journal of Higher Education Policy and Management, 34, 517-528. https://doi.org/10.1080/1360080X.2012.716000

Royal Navy (2016). Annex 21C. Ethos, Values and Standards. Section 11. https://www.tsoshop.co.uk/

Ryan, R. M., \& Deci, E. L. (2017). Self-Determination Theory: Basic Psychological Needs in Motivation, Development, and Wellness. New York: Guilford Publications.

Strauss, A. L. (1987). Qualitative Analysis for Social Scientists. Cambridge: Cambridge University Press. https://doi.org/10.1017/CBO9780511557842

Tsvetkova, M. (2015). Special Report: Russian Soldiers Quit over Ukraine. Reuters, May $10,2015$.

http://www.reuters.com/article/2015/05/10/us-ukraine-crisis-soldiers-specialreport-id USKBN0NV06Q20150510

War Cabinet (2015). Measures to Strengthen the Defence of Mariupol Are Taken: He War Cabinet Chaired by the President.

http://www.mil.gov.ua/en/news/2015/07/13/measures-to-strengthen-the-defence-of-m ariupol-are-taken-the-war-cabinet-chaired-by-the-president

Whitmore, B. (2013). Putin's Growing Threat Next Door. The Atlantic. http://www.theatlantic.com/international/archive/2013/12/ukraines-threat-to-putin/28 $\underline{2103}$

Wright, C., \& Schartner, A. (2013). “I Can't... I Won't?” International Students at the Threshold of Social Interaction. Journal of Research in International Education, 12, 113-128. https://doi.org/10.1177/1475240913491055

UT (2016). Cyborgs v Kremlin. Ukraine Today.

Ulio, J. A. (1941). Military Morale. American Journal of Sociology, 47, 321-330. https://doi.org/10.1086/218912

Yin, R. K. (2013). Case Study Research: Design and Methods. London: Sage Publications.

Zhukov, Y. M. (2007). Examining the Authoritarian Model of Counter-Insurgency: The Soviet Campaign against the Ukrainian Insurgent Army. Small Wars and Insurgencies, 18, 439-466. https://doi.org/10.1080/09592310701674416 